\title{
Thyroid function in children with nephrotic syndrome: A prospective hospital-based study
}

\author{
Mohamed Abd El-Aal Mohamed, Ahmed Monir Hegab, Eman Elsayed \\ Masoud. \\ Department, Faculty of Medicine, Sohag University, Sohag, Egypt
}

\begin{abstract}
Background. Nephrotic syndrome is a common kidney disease among children which is characterized by proteinuria, hypercholesterolemia, hypoproteinemia, and edema. The urinary losses of proteins including albumin and thyroid-binding globulin might affect the thyroid hormone levels in those children.

Objective. To assess the thyroid function in children with nephrotic syndrome during the nephrotic attack and after remission.

Methods. This was a prospective study conducted at the Pediatrics department, Sohag University Hospital, Sohag, Egypt over a one-year period (from January to December 2017). Data were collected from 51 children with nephrotic syndrome aged between 1 and 12 years old. The study participants were subjected to investigations including thyroid-stimulating hormone (TSH), thyroxin (T4), triiodothyronine (T3), serum urea, creatinine, cholesterol, triglycerides, albumin, total proteins, urinary albumin-tocreatinine ratio and 24 hours urinary proteins during the nephrotic attack and after remission.

Results. The mean age for the study participants was $6.1 \pm 2.9$ years. Thirty-one participants were males $(60.8 \%)$. The study found that serum TSH levels were elevated while serum Total T3 and Total T4 were reduced during the nephrotic attack. As regards the thyroid hormone status, we found true hypothyroidism in 12 patients $(23.52 \%)$ and subclinical hypothyroidism in 24 patients $(47.06 \%)$ during the nephrotic attack. However, only one patient (1.96\%) had true hypothyroidism and 14 patients $(27.45 \%)$ had subclinical hypothyroidism after remission. Conclusion. A large proportion of children with nephrotic syndrome had thyroid dysfunction in the form of either true (overt) or subclinical hypothyroidism during the nephrotic attacks. Therefore, monitoring the thyroid function during nephrotic attacks in those children is important.
\end{abstract}

Keywords: Nephrotic syndrome, hypothyroidism, T3, T4, TSH.

\section{Introduction}

Nephrotic syndrome is one of the most common kidney diseases that affect children of all age groups (1). In patients with nephrotic syndrome, there is a marked urinary loss of proteins, mainly albumin (2). If this loss of albumin was not fully compensated by increased hepatic production, hypoalbuminemia would develop as a consequence (3). Moreover, many other proteins such as 
SOHAG MEDICAL JOURNAL Vol. 24 No. 2 April 2020
Thyroid function in children with nephrotic syndrome

Eman Elsayed Masoud hormone-binding proteins are also lost in the urine of patients with nephrotic syndrome (4).

The thyroid hormones are transported in the circulation bound to proteins, mainly thyroid-binding globulin (TBG), prealbumin and albumin. Urinary losses of these proteins may lead to decreased levels of thyroid hormones unless their production is increased by the thyroid gland under the influence of thyroiddstimulating hormone (TSH) (5).

Several studies have documented urinary loss of thyroid hormones and thyroxin binding globulin (TBG) in patients with nephrotic syndrome (6). However, there is still a need to assess the effect of this urinary loss of thyroid hormones and thyroxin binding globulin on the clinical status of children with nephrotic syndrome and whether they require thyroid replacement therapy or not.

Therefore, this study aimed at assessment of the thyroid function in children with nephrotic syndrome during attacks and after remission.

\section{Patients and Methods}

This was a prospective observational study. children aged 0 to 12 years, admitted at the pediatric department, Sohag University Hospital with the diagnostic criteria for nephrotic syndrome; proteinuria( urinary protein level > $40 \mathrm{mg} / \mathrm{m}^{2} / \mathrm{hr}$., Hypoalbuminemia (serum albumin level $<2.5 \mathrm{gm} / \mathrm{dl}$ ), Hypercholesterolemia (serum cholesterol level $>250$ $\mathrm{mg} / \mathrm{dl}$ ) and edema (7), over a one-year period (from January to December 2017) were included in the study. Children with known thyroid diseases diagnosed before the onset of nephrotic syndrome and children with hypothalamic-pituitary axis disorders (central hypothyroidism) were excluded.

All studied children were subjected to full history taking and thorough physical examination. Laboratory investigations were done to fulfill the inclusion criteria of nephrotic syndrome and to assess the thyroid function in the study participants. TSH, total $\mathrm{T} 3$, total $\mathrm{T} 4$, serum creatinine, blood urea, serum cholesterol, serum triglycerides, total serum proteins, serum albumin, albumin-toglobulin ratio, and 24 hours proteins in urine were done during the attack and repeated after remission. Remission was defined as proteinuria less than 40 $\mathrm{mg} / \mathrm{m}^{2} / \mathrm{hr}$., 0 , or trace on Albustix for 3 consecutive days or urine albumin-tocreatinine ratio less than $0.2 \mathrm{mg} / \mathrm{gm}$. of creatinine (8).

The patients were classified according to their thyroid hormones status into 5 categories; overt (true) hypothyroidism if they had TSH levels above the normal range for age and TT4 and TT3 levels were below the normal range for age, subclinical hypothyroidism if they had TSH levels above the normal range for an age while TT4 and TT3 levels were within the normal range for age, true hyperthyroidism if they had TSH levels below the normal range for age and the TT4 and TT3 levels were above the normal range for age, subclinical hyperthyroidism if they had TSH level below the normal range for an age while TT4 and TT3 levels were within the normal range for age, Euthyroid status if they had TSH, TT4 and TT3 levels within the normal range for age (9). Written consent was taken from parents of patients included in the study. An approval from the research ethical 
SOHAG MEDICAL JOURNAL

Vol. 24 No. 2 April 2020
Thyroid function in children with nephrotic syndrome

Eman Elsayed Masoud committee at the Sohag Faculty of Medicine was obtained.

The statistical analysis was done using SPSS version 18. Data were presented as means and standard deviations for continuous variables, and as numbers and percentages for categorical variables. Comparisons between the mean levels of biochemical markers detected in the study participants during nephrotic attacks and after remission were done using paired sample t-test. p-value at 0.05 or less was set as statistically significant.

\section{Results}

Fifty-one children with nephrotic syndrome were included in the study. The mean age for the study participants was $6.1 \pm 2.9$ years, with an age range from 1 to 12 years. Thirty-one participants were males $(60.8 \%)$.

Table (1) shows the differences in the biochemical characteristics in children with nephrotic syndrome during the attack and after remission. The patient had significantly lower serum albumin, total serum proteins during the attack ( $\mathrm{p}$ value $<0.001$ ). Serum cholesterol, triglycerides, and $24 \mathrm{hr}$. urinary proteins were significantly higher (p-value <0.001) during the attack. However, there was no significant difference in the level of creatinine, urea, and albumin-to-globulin ratio during nephrotic attack and remission.

As regards the thyroid hormone levels, the patients had significantly higher serum TSH levels during the attack ( $\mathrm{p}$ value $<0.001)$. Serum total T3 and total T4 levels were significantly reduced during the attack (p-value $<0.001)$.

Table (2) shows thyroid hormone status in children during the attack and after remission. During the attack, overt (true) hypothyroidism was found in 12 patients $(23.52 \%)$ and 24 patients $(47.06 \%)$ had subclinical hypothyroidism, while the remaining 15 patients $(29.4 \%)$ had normal thyroid profile. However, after remission 36 patients $(70.59 \%)$ had normal thyroid profile, 14 patients $(27.45 \%)$ had subclinical hypothyroidism and only one patient (1.96\%) had overt hypothyroidism. No patient had true or subclinical hyperthyroidism during the attack or after remission. 
SOHAG MEDICAL JOURNAL Vol. 24 No. 2 April 2020
Thyroid function in children with nephrotic syndrome Eman Elsayed Masoud

\begin{tabular}{|l|l|l|l|}
\hline Variables & During attack & After remission & P-value \\
\hline $\begin{array}{l}\text { Serum creatinine } \\
\text { Mean } \pm \text { SD }\end{array}$ & $0.39 \pm 0.12$ & $0.41 \pm 0.08$ & 0.25 \\
\hline $\begin{array}{l}\text { Serum urea } \\
\text { Mean } \pm \text { SD }\end{array}$ & $20.16 \pm 7.23$ & $18.53 \pm 2.07$ & 0.29 \\
\hline $\begin{array}{l}\text { Serum Albumin } \\
\text { Mean } \pm \text { SD }\end{array}$ & $1.97 \pm 0.53$ & $3.32 \pm 0.34$ & $<0.001$ \\
\hline $\begin{array}{l}\text { total serum proteins } \\
\text { Mean } \pm \text { SD }\end{array}$ & $4.42 \pm 0.89$ & $7.02 \pm 0.35$ & $<0.001$ \\
\hline $\begin{array}{l}\text { Serum cholesterol } \\
\text { Mean } \pm \text { SD }\end{array}$ & $394.82 \pm 119.67$ & $191.45 \pm 21.75$ & $<0.001$ \\
\hline $\begin{array}{l}\text { Serum triglycerides } \\
\text { Mean } \pm \text { SD }\end{array}$ & $244.63 \pm 79.27$ & $134.71 \pm 26.47$ & $<0.001$ \\
\hline $\begin{array}{l}\text { 24hr urinary proteins } \\
\text { Mean } \pm \text { SD }\end{array}$ & $5673.16 \pm 5402.15$ & $196.51 \pm 48.60$ & $<0.001$ \\
\hline $\begin{array}{l}\text { Albumin-to-globulin ratio } \\
\text { Mean } \pm \text { SD }\end{array}$ & $0.76 \pm 0.29$ & $0.71 \pm 0.15$ & 0.31 \\
\hline $\begin{array}{l}\text { TSH } \\
\text { Mean } \pm \text { SD }\end{array}$ & $5.75 \pm 4.52$ & $4.27 \pm 3.31$ & $<0.001$ \\
\hline $\begin{array}{l}\text { TT3 } \\
\text { Mean } \pm \text { SD }\end{array}$ & $112.02 \pm 43.92$ & $141.52 \pm 42.82$ & $<0.001$ \\
\hline $\begin{array}{l}\text { TT4 } \\
\text { Mean } \pm \text { SD }\end{array}$ & $5.86 \pm 2.20$ & $8.13 \pm 2.21$ & $<0.001$ \\
\hline
\end{tabular}

Table (1): The biochemical markers in children with nephrotic syndrome during the attack and after remission.

\begin{tabular}{|l|l|l|}
\hline Thyroid status & During attack & After remission \\
\hline Euthyroid & $15(29.41 \%)$ & $36(70.59 \%)$ \\
\hline Subclinical hypothyroidism & $24(47.06 \%)$ & $14(27.45 \%)$ \\
\hline True hypothyroidism & $12(23.52 \%)$ & $1(1.96 \%)$ \\
\hline
\end{tabular}

Table (2): Thyroid status in the study participants during the attack and after remission.

\section{Discussion}

In children with nephrotic syndrome, urinary loss of thyroid hormones and thyroxin binding globulin (TBG) might impair the thyroid function in those children (10).

The current study demonstrated that children with nephrotic syndrome had significantly higher serum TSH levels and significantly lower serum total T3 and total T4 levels during nephrotic attacks compared to their levels during remission. This was associated with significantly reduced levels of serum albumin and serum total proteins during the nephrotic attack compared to their level after remission. This indicated that decreased levels of total T3 and total T4 might be attributed to the urinary loss of proteins including the thyroid-binding globulin.

These findings were in line with the finding of several other studies condcted on children with nephrotic syndrome. Iglesias et al reported that proteinuria leads to loss of thyroid hormones with subsequent stimulation of TSH 
SOHAG MEDICAL JOURNAL

Vol. 24 No. 2 April 2020
Thyroid function in children with nephrotic syndrome

Eman Elsayed Masoud production with the later return of thyroid function to normal with an improvement of the non-thyroidal disease (11). Feinstein et al found that reduced serum levels of $\mathrm{T} 4$ and $\mathrm{T} 3$ in patients with nephrotic syndrome may be due to decreased concentration of thyroid-binding globulin (4). Mohamed et al. reported that those patients with relapse had significantly lower levels of total serum proteins and albumin in comparison with cases in the remission and control group (12). Moreover, Guo et al found thyroid dysfunction in 73 of 164 patients with nephrotic syndrome. Serum TSH levels were significantly higher in patients with thyroid dysfunction while serum albumin, Free $\mathrm{T} 3$, Free T4, Total T3, and total T4 levels were significantly lower than in patients with euthyroid status (5). Similarly, Sawant et al reported that serum TSH level was elevated while total T3 and total T4 levels were significantly lower in patients with nephrotic syndrome compared to controls (2).

Our study showed that during a nephrotic attack about $47 \%$ of children with nephrotic syndrome had subclinical hypothyroidism, while overt hypothyroidism was found in $23 \%$ of the study participants. However, the study demonstrated that after remission only one patient had overt hypothyroidism and about $27 \%$ of the study participants had subclinical hypothyroidism.

In line with our findings, Choudhury reported that children with nephrotic syndrome had an increased risk of subclinical hypothyroidism especially in younger children (6). Moreover, Sahni et al reported that although most children with nephrotic syndrome were clinically euthyroid, they had an increased risk of subclinical hypothyroidism during the nephrotic attack with elevated TSH levels while serum T3 and T4 were within normal (14). Similarly, Afroz et al reported that patients with the nephrotic syndrome had a state of mild or subclinical hypothyroidism during proteinuria although they are clinically euthyroid (1).

\section{Conclusion}

A large proportion of children with nephrotic syndrome had thyroid dysfunction in the form of either overt or subclinical hypothyroidism during the nephrotic attacks. However, the majority of those patients restored normal thyroid function after remission. Monitoring the thyroid function during nephrotic attacks in those children is important.

\section{References:}

1- Ebadi A, Shirali S, Saki S, Daneghian $S$. Evaluating the thyroid function in pediatric Nephrotic syndrome. A study conducted in Ahvaz Iran. International Journal of Pharmaceutical Research;2016;5(2); 82-85-

2- Sawant SU, Chandran S, Almeida AF, Rajan MG. Correlations between oxidative stress and thyroid function in a patient with nephrotic syndrome. Int J Nephrol. 2011; 256420.

3-Afroz S, Khan AH, Roy DK. Thyroid function in children with nephrotic syndrome. Mymensingh Med J .2011; 20(3): 407-11.

4- Feinstein EI, Kaptein EM, Nicoloff JT, Massry SG. Thyroid function in patients with nephrotic syndrome and normal renal function. Am J Nephrol. 1982; 2(2):70-6.

5- Guo Q-Y, Zhu Q-J, Liu Y-F, Zhang H-J, Ding Y, Zhai W-S et al. Steroid 
SOHAG MEDICAL JOURNAL

Vol. 24 No. 2 April 2020

Thyroid function in children with nephrotic syndrome

Eman Elsayed Masoud

combined with levothyroxine to treat children with idiopathic nephrotic syndrome: a retrospective single-center study. Pediatric Nephrology. 2014;29(6):1033-8.

6- Choudhury J. A study on thyroid function test in children with nephrotic syndrome. Int J Contemp Pediatr 2016;3:752-4.

7-Banaszak B, Banaszak P. The increasing incidence of initial steroid resistance in childhood nephrotic syndrome. Pediatr Nephrol 2012(27);927-932.

8-Gipson DS, Massengill SF, Yola, Nagaraj S, Smoyer WE, Maha JD. Management of childhood-onset of nephrotic syndrome .pediatrics 2009; 124(2):747-57.
9- Cooper DS, Biondi B. Subclinical thyroid disease. The Lancet. 2012; 379(9821):11421154.

10-Park SJ, Shin JI. Complications of nephrotic syndrome. Korean Journal of Pediatrics. 2011; 54(8):322-328.

11- Iglesias P, Diez JJ. Thyroid dysfunction and kidney disease.Eur $J$ Endocrinol, 2009; 160:503-515.

12- Mohamed S, Zanon M, Elaskary A, Abdel-aal M, Abdelrahman $Y$ et al. Evaluation of thyroid function, oxidative stress and anti-oxidant in Egyptian children with nephrotic syndrome. Kidney Research Journal, 2016, 6: 9-14.

13- Shahni V, Nanda S, Gehlawat V, Gathwala G. Hypothyroidism in nephrotic syndrome in children. IOSR-JDMS. 2014;13(8):7-11. 